\begin{tabular}{|l|l|l||}
\hline \multicolumn{2}{|c|}{ PublisherInfo } \\
\hline \hline PublisherName & $:$ & Palgrave Macmillan UK \\
\hline \hline PublisherLocation & $:$ & London \\
\hline \hline PublisherImprintName & $:$ & Palgrave Macmillan \\
\hline
\end{tabular}

\title{
Methods explained: Data reduction and model selection techniques
}

\begin{tabular}{|l|l|l||}
\hline \multicolumn{3}{|c|}{ ArticleInfo } \\
\hline \hline ArticleDOI & $:$ & $10.1057 /$ palgrave.elmr.1410141 \\
\hline \hline ArticleCategory & $:$ & Feature \\
\hline \hline ArticleFirstPage & $:$ & 62 \\
\hline \hline ArticleLastPage & $:$ & 67 \\
\hline \hline & & RegistrationDate $:$ 2007-9-14 \\
ArticleHistory & $:$ & OnlineDate $\quad$ 2007-9-14 \\
\hline \hline ArticleCopyright & $:$ & Crown copyright2007 \\
\hline \hline
\end{tabular}


Graeme Chamberlin, ${ }^{\text {Aff1 }}$

Aff1 Office for National Statistics

\section{Outlines problems dealing with large numbers of variables, explaining techniques available toreduce them to more manageable proportions.}

Researchers and analysts now have access to increasingly large data sets. This article outlines some of the problems of dealing with alarge number of variables and explains some of the techniques that can be used to reduce the number of available indicators to a moremanageable size. This can be helpful in analysing the data or in modelling and forecasting work.

The Full Text of this article can be found on the National Statistics website (http://www.statistics.gov.uk/elmr/09_07/downloads/ELMR09_07MethodsExplained.pdf) 